\title{
Tilamallit nautatilan tuotannon kehittämisen apuvälineenä
}

\author{
Hannu Viitala, Leena Kärkkäinen, Piia Kekkonen \\ Savonia-ammattikorkeakoulu, PL 72, 74101 Iisalmi, etunimi.sukunimi@savonia.fi
}

\section{TIIVISTELMÄ}

Suomen maidontuotannossa lehmien keskituotos on korkea, mutta peltohehtaaria kohti laskettuna maitotuotos on alhainen. Eläintiheys Pohjois-Savossa on vain noin 0,9 ny/ha. Tämä johtaa siihen, että useilla tiloilla pellon satopotentiaalia ei tarvitse hyödyntää täysimääräisesti. Peltoreservi puskuroi vuosittaisia satovaihteluita ja antaa mahdollisuuden kotieläintuotannon kehittämiseen. Peltoreservi johtaa tilatasolla helposti siihen, että lähimpänä talouskeskusta olevia lohkoja viljellään intensiivisesti ja kaukana sijaitsevia tai muuten epäedullisia lohkoja viljellään laajaperäisesti. Tilamallin avulla selvitettiin säilörehun tuotantokustannusta eri lannoitemäärillä ja erilaisilla korjuumenetelmillä. Tavoitteena oli antaa rehuntuotantokokonaisuuden vaihtoehtoja navetan rehutilauksen toimittamiseksi. Tilamalleissa on vertailtu korjuuketjun, logistiikan, peltojen tilusrakenteen ja peltojen etäisyyden vaikutuksia rehun tuotantokustannuksiin. Keskimääräinen säilörehun satotaso on noin 4500 kuiva-ainekiloa hehtaarilta. Säilörehun satotasoja nostamalla voidaan parantaa tilan taloutta monella sektorilla. Kun saadaan enemmän rehua, tilan kotieläintuotantoa voidaan kehittää. Tilojen säilörehusatotasojen kehittämiseen otettiin työkaluiksi satovastelaskuri ja tilamallit. Typen satovastelaskurissa säilörehun kuiva-ainesato määritettiin satovastefunktiolla pellon kasvukunnon ja lannoitustason perusteella. Satovastefunktio on määritetty Maaningan ja Ruukin kenttäkokeiden tuloksista kivennäismaille. Tilamallien avulla selvitettiin, miten paljon kaukana oleviin hyviin peltoihin kannattaa panostaa, ja milloin välimatka kumoaa hyvän peltolohkon kasvukunnon hyödyn. Tilamalleissa oli mukana 49 erilaista versiota, joissa korjuuketju ja peltojen kasvukunto vaihtelivat tilalla, jolla on 140 lehmää ja 160 hehtaaria peltoa. Rehunkorjuuketjuina oli ajosilppuri, noukinvaunu, pyöröpaalain tai tarkkuusilppuri. Peltojen kasvukunnon vaihtelua seurattiin myös eri etäisyyksillä tilan pääkeskuksesta olevilla peltolohkoilla. Tilamallien vertailussa tuli esille, että säilörehulohkojen kasvukunnon ollessa erittäin hyvä tai hyvä ostorehuja ei tarvita. Jos kasvukunto on erittäin hyvä, peltoalaa jää valkuais- tai myyntikasvien tuotantoon. Peltojen kasvukunnon ollessa tyydyttävä tai heikko, joudutaan turvautumaan ostorehuihin, jotta saadaan karjan energiantarpeet tyydytettyä. Tilamallia haluttiin testata myös käytännössä lypsykarjatiloilla, joilla oli panostettu nurmentuotantoon. Tilojen säilörehun satotaso saatiin selville laskemalla karjan tarvitsema energiamäärä ja vähentämällä siitä ostorehujen energiamäärä. Tuloksena oli säilörehun nettosato. Se oli huomattavasti alempi kuin tilojen oma arvio satotasosta. Korjuu-, säilöntä- ja ruokintatappioiden määrittämisen lisäksi tarvitaan työkalu, jolla yrittäjä tai satotasomittaaja voi helposti määrittää oletussatotason rehun käytön perusteella, kuten se on NuRa-tilamalleissa tehty.

Asiasanat: nurmi, säilörehu, tuotantokustannus 


\section{Johdanto}

Tilamallin avulla selvitettiin säilörehun tuotantokustannusta eri lannoitemäärillä ja erilaisilla korjuumenetelmillä. Tavoitteena oli antaa rehuntuotantokokonaisuuden vaihtoehtoja navetan rehutilauksen toimittamiseksi. Tilamallit on laadittu Savonia-ammattikorkeakoulun REKKA-hankkeessa 2012-2014 laadittujen tilamallien pohjalta, jossa verrattiin korjuuketjun ja logistiikan vaikutuksia rehun tuotantokustannuksiin. Maaseuturahaston rahoittaman, Luonnonvarakeskus Maaningan, Pro Agrian ja Savonia-ammattikorkeakoulun toteuttaman Nurmet Rahaksi -hankkeen tilamallissa tähän on liitetty säilörehun riittävyys ja ostorehujen tarve lypsykarjalle.

Keskimääräinen säilörehun satotaso on noin 4500 kuiva-ainekiloa hehtaarilta. Syy alhaisiin satoihin saattaa olla se, että peltoa on paljon suhteessa eläinmäärään. Satotason kehittäminen ei ole silloin ole ensimmäisenä mielessä. Säilörehusatotasojen mittaamiseen ei ole ollut olemassa hyviä menetelmiä ja ne arvioidaan helposti yläkanttiin. Tilamalli-laskelman avulla saamme selville tilan keskimääräisen nettosadon säilörehusta. Sen tietämällä voi lähteä kehittämään viljelymenetelmiä ja parantamaan satotasoa.

Säilörehun satotasoja nostamalla voidaan parantaa tilan taloutta monella sektorilla. Kun saadaan enemmän rehua, tilan kotieläintuotantoa voidaan kehittää. Vapautunut peltoala voidaan käyttää valkuaisrehuntuotantoon. Vapautunut peltoala voidaan käyttää myös myyntikasvituotantoon. Tilojen säilörehusatotasojen kehittämiseen otettiin työkaluiksi satovastelaskuri ja tilamallit. Tilamalleissa oli kaksi tavoitetta: säilörehun kuiva-ainesato $10000 \mathrm{~kg}$ hehtaaria kohti ja Nitraattiasetuksen haastaminen.

\section{Aineisto ja menetelmät}

Satovastelaskurilla voidaan määrittää tarvittavan lannoituksen riittävään rehusatoon eri satopotentiaaliin yltävillä lohkoilla. Typen satovastelaskurissa säilörehun kuiva-ainesato määritetään satovastefunktiolla:

$\mathrm{y}=3436,4+47,401 * \mathrm{~N}$-lannoitus $-0,0605 * \mathrm{~N}$-lannoitus ${ }^{2}$,

joka on määritetty Maaningan ja Ruukin kenttäkokeiden tuloksista kivennäismaille (Virkajärvi ym. 2018, 73). Näin saatu säilörehun kuiva-ainesato korjataan korjauskertoimella (70\%). Jos nämä lukemat eivät täsmää, säilörehualan kasvukuntoa laskelmassa muutetaan. kasvukuntovaihtoehdot ovat: erittäin hyvä $120 \%$, hyvä $90 \%$, tyydyttävä $75 \%$ ja heikko $60 \%$ (Kuva 1). Erittäin hyvä kasvukunto $120 \%$ tarkoittaa, että kyseiset pellot ovat $20 \%$ paremmassa kunnossa kuin koeaseman pellot. Laskurin avulla saatu satotaso täsmätään tilan lehmien ja nuorkarjan tarvitseman rehun kanssa.

Tilamallien avulla selvitettiin, miten paljon kaukana oleviin hyviin peltoihin kannattaa panostaa, milloin välimatka kumoaa hyvän peltolohkon kasvukunnon hyödyn ja miten paljon pellon kasvukunnon parantamiseen kannattaa panostaa. Pohjana laadinnassa on ollut REKKA-hankkeessa 2012-2014 laaditut Excel-ohjelmaan tehdyt tilamallit, joissa on verrattu korjuuketjun ja logistiikan vaikutuksia rehun tuotantokustannuksiin. Tilan lehmämäärä oli 140 ja pelto oli 160 hehtaaria. Rehunkorjuuketjuina oli ajosilppuri, noukinvaunu, pyöröpaalain ja tarkkuussilppuri. Lisäksi varioitiin sivutilan etäisyydellä 25 tai 50 kilometriä. Lisäksi mukana oli seitsemän eri vaihtoehtoa peltojen kasvukunnoista. Neljässä peltojen kasvukunto oli koko alalla sama ja vaihteli erittäin hyvästä välttävään. Kahdessa mallissa peltojen kasvukunto vaihteli niin, että toisessa tilakeskuksen lähellä olevat pellot olivat parhaita ja toisessa puolestaan kauimmat pellot olivat parhaita. Vertailuksi mukana oli Rekka-hankkeen malli, joka päivitettiin uudemmilla hintatiedoilla. Mukana oli siis seitsemän tilamallia ja niissä seitsemän vaihtoehtoa eli yhteensä 49 erilaista tilamallia. 




Kuva 1. Pellon kasvukunnon vaikutus nurmen satotasoon erilaisilla typpilannoitustasoilla

Tilamallit on laadittu Savonia-ammattikorkeakoulun REKKA-hankkeen tilamallin pohjalta: 2 robotin lypsykarja, 140 lehmää, keskituotos 90001 vuosi-1 $^{-1}$, uudistus 40\%, joten uudistushiehoja poikii keskimäärin 56 vuodessa. Mikäli peltojen kasvukunto on tyydyttävä (maksimisatopotentiaali $75 \%$ ) ja lannoitus tehdään maksimityppitasoilla, säilörehua tarvitaan ruokinnassa yli 760000 kuiva-ainekiloa, kun kotoista viljaa käytetään 110000 kuiva-ainekiloa ja ostoväkirehuja 260000 kg ka.

\section{Tulokset}

Tilamallien vertailussa tuli esille, että parhaimpiin lohkoihin kannattaa panostaa. Niistä saadun sadon arvo kattaa lohkon sijainnista johtuvat kuljetuskustannukset. Toisaalta lohkojen kasvukunnon parantamiseen kannattaa panostaa, koska vain hyväkuntosilla pelloilla rehuntuotanto on kannattavaa. Säilörehulohkojen kasvukunnon ollessa erittäin hyvä tai hyvä ostorehuja ei tarvita. Jos kasvukunto on erittäin hyvä, peltoalaa jää valkuais- tai myyntikasvien tuotantoon. Peltojen kasvukunnon ollessa tyydyttävä tai heikko, joudutaan turvautumaan ostorehuihin, jotta saadaan karjan energiantarpeet tyydytettyä.

\section{Tilamallit}

Mikäli kaikkien säilörehulohkojen kasvukunto on erittäin hyvä (maksimisatopotentiaali 120\%) ja lannoitus tehdään maksimityppitasoilla, ostorehuja ei tarvita ja lisäksi 20 ha pienempi säilörehun tuotantoala riittäisi kattamaan karjan energian tarpeen. Peltoalaa ei käytännössä voisi pienentää, koska tarvitaan lannanlevitysalaa. Pienentynyt säilörehualantarve mahdollistaisi esimerkiksi valkuaiskasvituotannon.

Säilörehun tuotantokustannus on alhaisin, mikäli säilörehulohkojen kasvukunto on erittäin hyvä ja vastaavasti kallein mikäli säilörehulohkojen kasvukunto on välttävä. Säilörehun korjuumenetelmä (koneketju) ja säilörehulohkojen etäisyys tilakeskuksesta vaikuttavat säilörehun tuotantokustannukseen.

Edullisista säilörehuntuotanto on lähimpänä talouskeskusta sijaitsevilla pelloilla, kun rehu korjataan

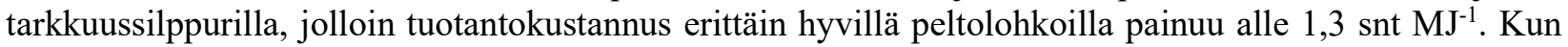
rehu korjattaisiin noukinvaunulla ja pyöröpaalaimella, päästään myös alle 1,4 snt $\mathrm{MJ}^{-1}$ tuotantokustannukseen. 
Suomessa parhaimmilla tiloilla tuotetaan säilörehua alle 1,5 snt $\mathrm{MJ}^{-1}$ ja keskimäärin säilörehun tuotantokustannus on noin 2,5 snt $\mathrm{MJ}^{-1}$. Hyvän sadon merkitys tuotantokustannuksen muodostumisessa on suuri, joten peltojen kasvukuntoon kannattaa panostaa.

Kalleinta säilörehuntuotanto on kauimpana talouskeskuksesta sijaitsevilla kasvukunnoltaan välttävillä pelloilla (sivutila $50 \mathrm{~km}$ päässä), kun rehu korjataan ajosilppurilla: 3,6 snt $\mathrm{MJ}^{-1}$. Noukinvaunulla ja tarkkuussilppurilla tuotantokustannus menee tällöin myös yli 3 snt $\mathrm{MJ}^{-1}$. Mikäli kaukana sijaitsevat pellot olisivat kasvukunnoltaan erittäin hyviä, niin tuotantokustannukset $\left(\mathrm{snt} \mathrm{MJ}^{-1}\right.$ ) puolittuisivat.

\section{Tilaesimerkit}

Tilamallilla haluttiin testata myös käytännössä ja sitä varten valittiin kaksi lypsykarjatilaa. Molemmat tilat olivat panostaneet nurmentuotantoon. Satotaso saatiin selville laskemalla karjan tarvitsema energiamäärä ja vähentämällä siitä ostorehujen energiamäärä. Loput energiasta saadaan oman pellon tuotannosta. Energian tarpeen laskennassa huomioidaan meijeriin mennyt maito ja säilörehu huomioidaan nettosatona, joten tilamallissa hävikit ovat pois laskennasta. Panokset ovat sen sijaan mukana kokonaisuudessaan. Katetuottolaskelmien tulokset ovat siis heikommat kuin laskelmissa, joissa satomäärä määritetään bruttosatona tai arviona.

Tilamallilla testattiin kaksi lypsykarjatilaa, joissa ennakkoon tiedettiin säilörehuntuotanto tehokkaaksi. Tilat olivat tavanomaisessa tuotannossa eli tiloilla käytetään karjanlannan lisäksi keinolannoitteita. He olivat salaojittaneet pellot ja käytössä oli salaojien huuhtelulaitteet. Toisella tilalla käytettiin suorakylvöä hietamoreenimaiden takia. Kyntämällä pellosta olisi saatu nostettua valtava määrä kiviä pintaan. Täydennyskylvö nurmille kuului molempien tilojen keinovalikoimaan pitämään nurmen kasvukykyä yllä. Tilalla 1 ei kalkita peltoja suorakylvön ja runsaan karjanlannan levityksen takia, mutta tilalla 2 on panostettu kalkitukseen.

Taulukossa 1 esitellään tilaesimerkkien tuotannon tehokkuudesta kertovia lukuja. Tilan 2 nautayksikkömäärä hehtaaria kohti on huomattavasti pienempi kuin tilan 1. Tilalla 2 on kasvatettu peltomäärää ja suunnitteilla on eläinmäärän lisääminen. Navettaremonttia ei oltu vielä tutkimushetkellä ennätetty tehdä, joten siksi lukema on tilan 2 osalta harhaanjohtava. Samoin meijerimaidon määrä hehtaaria kohti on tilalla 2 alhainen. Säilörehun hehtaarisadot molemmilla tiloilla on keskimääräisiä. Pitää kuitenkin ottaa huomioon, että tässä tilamallissa lasketaan nettosadot, joista sekä säilörehun että maidon hävikit ovat pois laskuista.

Taulukko 1. Tilaesimerkkien tuotantolukuja

\begin{tabular}{|l|l|l|l|}
\hline Tila & ny ha $^{-1}$ & meijerimaitoa $1 \mathrm{ha}^{-1}$ & säilörehua kg ka ha-1 \\
\hline Tila 1 & 1,14 & 9000 & 5700 \\
\hline Tila 2 & 0,64 & 4010 & 4750 \\
\hline
\end{tabular}

\section{Tulosten tarkastelu}

Tilamallien perusteella säilörehua kannattaa viljellä parhailla pelloilla, jolloin niistä saadaan parhaimmat sadot, vaikka kasvukunnoltaan parhaimmat lohkot olisivat kauempana talouskeskuksesta (tilamalleissa 25 ja 50 km etäisyydellä). Hyvä sato kompensoi tehokkaasti kasvavia logistiikkakustannuksia. 
Tilaesimerkit paljastivat merkittävän ristiriidan säilörehun satotasojen määrittämisessä. Rehun tarpeeseen ja käyttöön perustuvalla tilamallit-laskelmalla säilörehusadot ovat huomattavasti alhaisemmat kuin viljelijän arvio satotasosta tai satotasomittausten tulokset ovat. Korjuu-, säilöntä- ja ruokintatappioiden määrittämisen lisäksi tarvitaan työkalu, jolla yrittäjä tai satotasomittaaja voi helposti määrittää oletussatotason rehun käytön perusteella, kuten se on NuRa-tilamalleissa tehty.

\section{Johtopäätökset}

Tilamallit osoittivat, että hyvän kasvukunnossa oleviin peltoihin kannattaa panostaa riippumatta siitä, kuinka kaukana talouskeskuksesta ne ovat. Hyvä sato kannattaa hyödyntää sieltä, mistä se on saatavilla. Jopa logistiikkakustannukset saadaan näin kompensoitua.

Kaksi tilaesimerkkiä osoittivat tarpeen mitata nykyistä tarkemmin säilörehusatoja. Laskelmassa huomioidaan nautojen kautta hyödynnetty nurmisato ja näin saadut hehtaarisadot olivat reilusti pienempiä kuin tilojen oma arvio satotasosta. Ero voi johtua erilaisista tavoista mitata tai arvioida satoa. Vielä ei ole kovin yleistä satojen punnitseminen vaa'alla. Se antaa luotettavan tiedon korjuuhetken sadosta. Siihen, kuinka paljon nurmisadosta tulee lehmien syötäväksi, vaikuttaa korjuuhetken sadonmittausten jälkeen säilöntätappiot ja ruokintatappiot. Näiden määrästä on jonkinlaisia arvioita, mutta Savoniaammattikorkeakoulussa kiinnostuttiin tästä aiheesta siinä määrin, että tulevassa hankkeessa paneudutaan vielä tarkemmin tähän kysymykseen.

\section{Kiitokset}

Kiitämme tutkimukseen osallistuneita tiloja. Samoin kiitos Euroopan maaseudun maaseuturahastolle ja muille Nurmet Rahaksi-hankkeen rahoittajille. He kaikki ovat olleet mahdollistamassa tämän tutkimuksen tekemisen.

\section{Kirjallisuus}

Virkajärvi, P., Kykkänen, S., Hyrkäs, M., Korhonen, P., Hartikainen, M., Kärkönen, A. \& Toivakka, M. 2018. Uudet typpilannoituskokeet haastavat vanhat käsitykset nurmien satovasteista. Esitelmä- ja posteri-tiivistelmät. Maataloustieteen päivät 2018. 10.-11.1.2018 Viikki, Helsinki. Suomen Maataloustieteellisen Seuran Tiedote 34. https://journal.fi/smst/issue/view/5992 